\title{
The Relationship between LGBT Executives and Firms' Value and Financial Performance
}

\author{
Isabel Costa Lourenço ${ }^{1}$, Donatella Di Marco ${ }^{1,2}$, Manuel Castelo Branco ${ }^{3, * \mathbb{D}}$, Ana Isabel Lopes ${ }^{1}$ (D), \\ Raquel Wille Sarquis ${ }^{4}$ and Mark T. Soliman ${ }^{5}$
}

check for updates

Citation: Lourenço, Isabel Costa, Donatella Di Marco, Manuel Castelo Branco, Ana Isabel Lopes, Raquel Wille Sarquis, and Mark T. Soliman. 2021. The Relationship between LGBT Executives and Firms' Value and Financial Performance. Journal of Risk and Financial Management 14: 596 https://doi.org/10.3390/jrfm 14120596

Academic Editors: Ştefan

Christian Gherghina and Anastasios G. Malliaris

Received: 31 October 2021 Accepted: 6 December 2021 Published: 10 December 2021

Publisher's Note: MDPI stays neutral with regard to jurisdictional claims in published maps and institutional affiliations.

Copyright: (C) 2021 by the authors Licensee MDPI, Basel, Switzerland. This article is an open access article distributed under the terms and conditions of the Creative Commons Attribution (CC BY) license (https:// creativecommons.org/licenses/by/ $4.0 /)$
1 Business Research Unit (BRU-IUL), Instituto Universitário de Lisboa (ISCTE-IUL), 1649-026 Lisbon, Portugal; isabel.lourenco@iscte.pt (I.C.L.); ddimarco@us.es (D.D.M.); Ana.Isabel.Lopes@iscte-iul.pt (A.I.L.)

2 Department of Social Psychology, Universidad de Sevilla, 41004 Sevilla, Spain

3 Faculty of Economics, University of Porto, CEF.UP., OBEGEF, 4050-313 Porto, Portugal

4 School of Economics, Business and Accounting, University of São Paulo (USP), São Paulo 13566-590, Brazil; raquel.sarquis@usp.br

5 Marshall School of Business, University of Southern California, Los Angeles, CA 90089, USA; msoliman@marshall.usc.edu

* Correspondence: mcbranco@fep.up.pt

\begin{abstract}
Drawing on resource-based theory, we analyze the relationship between having LGBT executives in a firm's leadership positions and its value and financial performance. The existence of LGBT executives is considered to be associated with employee and customer goodwill towards LGBT-friendly policies and practices and to lead to human capital and reputational benefits. Our findings suggest that there is a positive effect of the presence of LBGT executives on a firm's value, both directly and indirectly, through its effect on the firm's financial performance. We interpret this as suggesting that besides the direct effect of the existence of LGBT executives on a firm's value, an indirect effect also exists, mediated through financial performance, presumably through the effect that this has on employee and customer goodwill towards LGBT-friendly policies and practices. As far as we are aware, our study is the first to examine the impacts of the presence of LGBT executives, as well as distinguish between its direct and indirect effects on firm value.
\end{abstract}

Keywords: financial performance; LGBT; market value; resource-based theory; sexual orientation and identity; simultaneous equations

\section{Introduction}

In recent years, the composition of society has changed rapidly, becoming more diverse and heterogeneous (van Knippenberg and Mell 2016). According to these societal changes, many Western countries have tried to answer to the need to create fair and inclusive environments for everybody through the promotion and implementation of a legislative framework in defense of people's equal rights (e.g., the Civil Rights Act in 1964, in the United States; the Employment Equality Directive in 2000, in the European Union). One of the environments in which it is possible to observe the diversification of society is the workplace, which is becoming a melting pot of people from different social and identity groups in terms of age, sex, ethnicity, religion, gender identity, and sexual orientation. Hence, the traditional range of diverse groups presented at work is wider, and this creates a new reality that organizations need to manage.

Until now, a sense of social justice, equality, and legal compliance has promoted the efforts of researchers and practitioners to identify those organizational (e.g., policies and culture) and individual barriers (e.g., prejudice and negative stereotypes) that prevent the creation of an inclusive work environment and equal opportunities of career development (e.g., Roberson and Park 2007). However, data about diverse people at the upper echelons reveal that women still remain underrepresented, occupying no more than $10 \%$ of management positions (Fitzsimmons and Callan 2020), while other diverse groups (e.g., 
people with disabilities and lesbian, gay, bisexual, and transgender people) are even less represented.

Beyond the moral obligation and social justice issues related to offering equal career opportunities to everybody, researchers and practitioners have started to emphasize the opportunities made available by creating a diverse and inclusive work environment (Stavrou and Ierodiakonou 2018). In fact, in line with the increasing awareness of the business case for diversity, organizations have started to look at diversity as a source of competitive advantage (Arenas et al. 2017). A recent study carried out with more than 1000 organizations in 12 countries showed that greater diversity leads to better financial performance (McKinsey and Company 2018). Specifically, organizations with more gender and ethnic diversity at the top management level are those that obtain above-average profits. Research suggests that fostering diversity allows firms to retain talent and team cohesion, increase creativity and innovation, and foster career development (e.g., Tejeda 2006; Farndale et al. 2015), thus representing a strategic choice (Burdenson and Van der Vegt 2018). Despite such recent insights, the business case for diversity still remains an unexplored field of research (Farndale et al. 2015), and few studies (e.g., Al-Shaer and Zaman 2016; Cook and Glass 2016) offer empirical support for the impact of diversity at the upper echelons on organizational financial performance.

Research on diversity at the upper echelons of firms has focused on visible diversity, such as gender and ethnic diversity. However, in the last years, invisible identities (e.g., religion, sexual orientation) have been receiving attention (Roumpi et al. 2020). Sexual orientation and gender identity might be considered as invisible identities to the extent that it is necessary for lesbian, gay, bisexual, and transgender (LGBT) workers to engage in proactive action to disclose their sexual orientation or gender identity. Adopting LGBTfriendly policies can have a positive impact on those workers that have not disclosed their sexual orientation or gender identity at the workplace (Huffman et al. 2008; Badgett et al. 2013; Cook and Glass 2016). Being authentic at work has been related with higher workers' commitment, job satisfaction, and well-being (McFadden 2015; Di Marco et al. 2018), which, in turn, can contribute to positive organizational outcomes. One of the goals of such policies should be to guarantee the same options, in terms of career development, to everybody, eliminating those barriers that could create a glass ceiling. However, once these policies achieve the goal of propelling visible LGBT people to the upper echelons, how do stakeholders and shareholders react? Although research offers empirical support for the relationship between LGBT-friendly policies and practices and organizational financial performance, we do not know the impact of having visible LGBT people at the upper echelons of a business. The goal of this study is to answer this question.

Given the paucity of research about the business case of LGBT people being in managerial positions, this study analyzes the extent to which visible LGBT people in the executive positions of a firm have a positive impact on its value. We examine both the possibility of a direct impact and the possibility of an indirect one mediated through financial performance. In order to answer this question, we rely on the list of 100 leading LGBT executives published by OUTstanding and The Financial Times (FT). Using a matched sample methodology, we examine whether the listed firms in which these leading LGBT executives are working outperform firms from a matched sample based on country and size.

The framework of this study draws upon the integration of the theoretical and empirical contributions about the business case of diversity, the Corporate Social Responsibility (CSR) literature (Bowen 1953; Colgan 2011), and the resource-based perspective (Barney 1991; Branco and Rodrigues 2006; Barney et al. 2011; Barney et al. 2021). The resource-based perspective posits that the internal characteristics of an organization and its resources can be linked to organizational performance. One of these resources is the human capital, which can represent a competitive advantage compared with competitors (Jiraporn et al. 2019). 
This paper contributes to the existing literature in various ways. Firstly, it provides information about the business case of diversity by examining the reputational effects of the presence of LGBT executives in firms' leadership teams in terms of their economic impacts. Secondly, the article sheds light on the importance of focusing on invisible diversity, such as sexual orientation and gender identity - a minority group that has been overlooked in the literature. Finally, by using simultaneous equations, we distinguish the effects on financial performance and on market value.

The paper is structured as follows. The next section provides the background and reviews relevant literature. The development of hypotheses is presented in Section 3. Section 4 describes the research design. In Section 5, research findings are presented. A discussion and concluding remarks are presented in the final section.

\section{Conceptual Framework}

\subsection{The Business Case for Diversity at the Top}

A large body of research underlines the effects of diversity on several organizational outcomes (e.g., Tejeda 2006; Farndale et al. 2015; Arenas et al. 2017; Burdenson and Van der Vegt 2018). According to the business case, when well managed (Özbilgin et al. 2016), diversity might positively impact those outcomes that create value for organizational stakeholders and shareholders. The basic assumption of the business case for diversity is that organizations can have a financial benefit by implementing policies that allow people to be authentic at work (Kossek and Pichler 2007). This idea has been empirically supported by studies that have demonstrated that the wise management of diversity leads to higher innovation, creativity, team performance, talent retention, and group cohesion (e.g., Cronin and Weingart 2007; Özbilgin et al. 2016; Mallory et al. 2017; Jiraporn et al. 2019). However, some other studies have showed mixed results (Randel and Jaussi 2003), and diversity has been associated with negative consequences, such as higher conflict (Özbilgin et al. 2016). The reason for such mixed results might lie in the lack of acknowledgement of those internal and external factors that might intervene in the effectiveness of the adoption of diversity policies and practices. In that sense, the perception of an adverse diversity climate (Gonzalez and DeNisi 2009) and the political and legislative context (e.g., Everly and Schwarz 2015; Roumpi et al. 2020) play a role in the relationship between diversity policies and practices, firm productivity, and return on profit.

Another factor that might determine financial performance is related to the composition of the corporate board, in terms of the extent to which having diverse people at the upper echelons can represent or promote a competitive advantage for the organization. To answer this question, many studies have been published devoted to exploring the topic of diversity on managing boards and its implications (Post and Byron 2015; Cabrera-Fernández et al. 2016; Halliday et al. 2021; Kyaw et al. 2021b), focusing mostly on the inclusion of women. Even in this case, the evidence offers mixed results (Post and Byron 2015). Some findings supported the business case for diversity, showing that increasing the number of women at the top of a company leads to positive outcomes in terms of corporate strategic decisions, participation, ethical behaviors, and firm profitability (Nielsen and Huse 2010; Post and Byron 2015). However, in their meta-analysis, Post and Byron (2015) found that firms with higher female representation on the board tend to present higher accounting returns but not necessarily better market performance. They found the positive relation between women on the board and accounting returns to be more positive in countries with stronger shareholder protections. They also found that the relationship between women on the board and market performance is positive in countries with greater gender parity. Such mixed results showed that further research is necessary.

\subsection{Diversity in Management, CSR, and the Resource-Based Theory}

The business case for diversity in management and its impact on financial performance has been explained through the lens of the Corporate Social Responsibility (CSR) theory (Bowen 1953; Colgan 2011) and resource-based theory (Branco and Rodrigues 2006; Surroca 
et al. 2010; Barney et al. 2011; Lourenço et al. 2014; Shaukat et al. 2016; Tetrault Sirsly and Lvina 2019). CSR has to do with the responsibility organizations have "for their impacts on society" and implies the integration of "social, environmental, ethical, and human rights concerns" into their operations and strategy (European Commission (EC) 2011). The CSR issues pertaining to environmental aspects are crucial for the transition to a low-carbon economy (Ionescu 2020, 2021), but when one considers the pursuit of sustainable development overall, aspects such that of diversity become pivotal.

Organizations that behave socially responsibly might simultaneously pursue the moral case for diversity and the business case for diversity. Making fair and moral decisions with the aim of creating inclusive organizations for everybody increases the commitment of all workers', decreases turnover (Wang and Schwarz 2010), and generates positive repercussions in terms of higher organizational reputation (Branco and Rodrigues 2006). Thus, increasing diversity at the upper echelons might send a clear message to stakeholders and shareholders about organizational diversity values, which might have an impact on a firm's reputation and, consequently, on its financial performance. Offering diverse groups of people the same chances in terms of career development is not just fair but can also represent a strategic decision.

Considering diversity in management as an intangible strategic asset is in line with resource-based theory (Barney 1991; Barney et al. 2011; Barney et al. 2021). According to this theory, a firm's generation of sustainable competitive advantages depends on the effectiveness of the control and manipulation of those resources and capabilities which are valuable and rare, hardly imitable, and for which there is no perfect substitute available for their replacement (Barney et al. 2011). A popular definition of resources and capabilities is that of Barney et al. (Barney et al. 2011, p. 1300), who view them as "bundles of tangible and intangible assets, including a firm's management skills, its organizational processes and routines, and the information and knowledge it controls that can be used by firms to help choose and implement strategies". Firms' human capital and reputation are considered to be among the resources of greatest strategic importance (Surroca et al. 2010). Generating organizational commitment on the part of its employees and publicly favorable reputations are increasingly analyzed as rationales for a firm to engage in CSR. Firms that enjoy favorable reputations are deemed as more likely to have good relations with their stakeholders (including governments, suppliers, and community representatives).

While the presence of women at the top and its financial impact has been studied extensively (e.g., Al-Shaer and Zaman 2016; Arayssi et al. 2016; Cook and Glass 2016), other diverse groups have been under-researched. For instance, the presence of LGBT people at the upper echelons has been less explored, and only recently have several disciplines started to shed light on the implications of non-normative sexual orientations and gender identities at different organizational dimensions.

\subsection{LGBT People at the Upper Echelons}

For many years, research on inclusion at organizations has focused on visible diversity and on those minority or protected groups that are immediately recognizable as different (Roumpi et al. 2020). Women, people of color, and people with visible disabilities have been the focus of attention of many studies dedicated to the examination of the prejudicial dynamics that have developed at the organizational level and that might undermine the development of diverse groups of people's careers. However, visible diversities are not the only kinds of diversity. Quite recently, researchers have started to focus on those people whose diversity traits might not be immediately identified and who require the disclosure of their invisible identity. Sexual orientation and gender identity have been traditionally considered as invisible traits because they require the active action of LGBT people to disclose their identity (Clair et al. 2005; Ragins 2008). However, recent studies have started to challenge the idea of the disclosure of sexual orientation as the result of an individual choice (e.g., Clair et al. 2005; Ragins 2008), pointing out the role played by third-party 
actors (supervisors, co-workers) in outing those colleagues who do not desire to come out (Ragins 2004).

Non-normative sexual orientations and gender identities have been stigmatized for many years. LGBT workers have been victims of discrimination, and although, currently, many countries offer legislative tools to protect their rights, in many other countries, such rights are not recognized by law (Di Marco 2017). Moreover, despite the legal protection offered by some countries, subtle discrimination still exists (Einarsdóttir et al. 2015; Di Marco et al. 2018).

One of the consequences of neglecting sexual orientations and gender identity at the workplace has been their exclusion from those actions which aim to create inclusive work environments (Roumpi et al. 2020), such as work-personal life-balance policies, career development, etc. Not including LGBT people in such policies, as a result of overt and subtle discrimination, is one of the reasons for the lower rate of LGBT people being openly out in management positions (Fitzsimmons and Callan 2020).

Despite the scenario above described, organizations are changing slowly. LGBT people's inclusion has become an important aspect of corporate practices and policies, albeit with an exponential growth in importance in the past few years. In 1984, IBM was the first to adopt a written policy concerning non-discrimination that included sexual orientation (Hayworth 2008). Currently, according to the Corporate Equality Index (CEI) published by the Human Rights Campaign Foundation (HRCF), which evaluates how the major corporations in the USA treat their LGBT employees, consumers, and investors, $89 \%$ of firms include sexual orientation in their non-discrimination policy (Human Rights Campaign Foundation HRCF 2015). The evolution of LGBT corporate policies has been especially noteworthy in terms of "gender identity protections and transgender-inclusive healthcare coverage" (Human Rights Campaign Foundation HRCF 2015). Whereas in the first CEI report, published in 2002, only 5\% of employers protected their employees on the basis of gender identity, in the last report, $93 \%$ of businesses do so (Human Rights Campaign Foundation HRCF 2015). Moreover, the number of organizations that offer critical transgender-inclusive benefits has grown from no major business doing so in 2002 to 511 affirming such coverage today (Human Rights Campaign Foundation HRCF 2015). In line with this trend, between 1999 and 2013, the proportion of Fortune 500 companies including sexual orientation in their non-discrimination policies increased from $52 \%$ to 87\% (Sears and Mallory 2014). Regarding the topic of gender identity, whereas in 1999 only a handful of such companies included it in these policies, by 2013, the proportion was $41 \%$ (Sears and Mallory 2014). The importance that LGBT rights are assuming in the business world is evidenced by the fact that a major international financial institution, Credit Suisse, launched an LGBT Equality Index for investors, which tracks the stock market performance of LGBT-friendly companies, in 2013.

Studies about the inclusion of LGBT-friendly policies and practices have shown positive results at the organizational level. The research found that performance, firm value, stock value, credit ratings, competitiveness, innovation, and customer satisfaction (Johnston and Malina 2008; Wang and Schwarz 2010; Li and Nagar 2013; Sears and Mallory 2014; Shan et al. 2017; Pichler et al. 2018; Jiraporn et al. 2019; Chintrakarn et al. 2020; Hossain et al. 2020; Hur 2020; Fatmy et al. 2021; Kyaw et al. 2021a; Opall 2021; Patel and Feng 2021) increase when such types of policies are adopted. Thus, although the implementation of LGBT-friendly policies represents a cost for the organization, it is not penalized by either stakeholders or shareholders (Johnston and Malina 2008; Cook and Glass 2016) because of their positive financial return.

The likelihood of the adoption of such policies is affected by factors such as the genderdiverse composition of the board (Cook and Glass 2016), while the organizational financial effect of the adoption of LGBT policies and practices is affected by the political orientation of both the environment of the organization's headquarters and the board of directors (Roumpi et al. 2020). 


\section{Hypotheses Development}

We mentioned above that wise diversity management practices, such as the implementation of diversity policies and practices and the promotion of equal opportunities of career development, are viewed as a CSR issue that can lead to the creation of strategic resources and, in turn, to a firm's competitive advantage. Resource-based theory offers insight into how CSR measures can influence firms' financial performance (McWilliams and Siegel 2011). According to Lozano et al. (2015, p. 436), resource-based theory "offers a unique perspective to corporate leaders by providing an explanation of how internal resources can lead to proactive changes in the company, especially if they were to consider environmental issues, as well as the rights and responsibilities of the firm, internally and externally".

The economic impacts of corporate LGBT practices and policies that Sears and Mallory (2014) identified are mainly related to human capital and reputation. According to these authors, the most commonly mentioned benefits resulting from LGBT-friendly policies include a heightened ability to recruit and retain the best talent, increased productivity by LGBT employees who feel valued and comfortable at work, and employee relations and morale. Moreover, according to Sears and Mallory (2014), many companies have explained the economic success of LGBT-friendly policies as being due to the variety of ideas and innovations resulting from a diverse workforce. Other benefits of such policies are related to a better ability to serve diverse customers' needs and the aptness to fulfill public sector clients' requirements.

Johnston and Malina (2008, p. 607) explained the possible economic benefits of LGBTfriendly practices and policies by suggesting that they may elicit a "chain of causally linked phenomena within the firm". They describe such a process in the following manner: "a firm managing diversity can recruit more effectively and retain well-qualified employees. These higher-quality employees are better able to identify, understand, and satisfy diverse customers which, in turn, increases firm financial performance." Shan et al. (2017) provide evidence that companies presenting higher levels of corporate sexual equality present higher levels of labor productivity than companies with lower levels of such equality. Pichler et al. (2018) provide evidence of a positive relationship between LGBT-supportive corporate policies and factor productivity and employee productivity.

Based on the above, we expect that a company with LGBT executives will be able to initiate such a virtuous chain, not only because it is more likely to have more progressive LGBT-related policies and practices but also because having this type of executives will signal a more progressive environment in terms of LGBT rights. In effect, the reputational aspect is of the utmost importance in eliciting the chain of phenomena to which Johnston and Malina (2008) refer. As Wang and Schwarz (2010) underline, LGBT-friendly policies allow organizations to create a reputation of being progressive in terms of how LGBT workers are treated, and such a reputation may make the firm more attractive to wellqualified employees among the LGBT community.

Another aspect is the possible effect of LGBT-friendly policies and practices on customers. This effect is related to a firm's reputation regarding how it treats LGBT workers. As Wang and Schwarz (2010, p. 200) suggest, firms with more progressive policies and practices pertaining to LGBT issues may have a better reputation with potential customers of the LGBT community. Patel and Feng (2021) present evidence of a positive influence of LGBT workplace equality policies on customer satisfaction, both directly and through the mediation of marketing capability, although such relations are dampened by demand instability. We consider that a firm with executives who are publicly known as LGBT will, regardless of the actual policies in place, also enjoy a similar reputation. Hence, a similar relation with customers is likely to exist.

Considering LGBT-friendly corporate policies and practices as a CSR issue, its benefits may take different forms. Reviewing and synthesizing the contemporary business literature that focuses on the role of CSR to enhance firm value, Malik (2015) notes that those benefits may influence firm value both directly and indirectly. This author states that firms' superior 
quality social and environmental initiatives increase the value of a firm directly by way of their positive influence on stock market returns. The other forms of benefits, such as augmented employee productivity, enhanced operating efficiency, and improved relations with the firm's stakeholders, increase its revenues as well as profitability, which indirectly leads to a higher value of the firm. Given that the market value of a firm "takes into account the long-term impact of managerial decisions on the firm's operating performances, including sales revenues, profits, cash flows, and growth prospects" (Malik 2015, p. 426), an indirect effect on a firm's market values of LGBT executives being on its leadership team, and thus on its better financial performance, is likely to occur. As Wang and Schwarz (2010, p. 200) stated, if LGBT-friendly practices and policies result in financial efficiency gains, the expected market value of the firm should increase.

Hence, we analyze the possible direct and indirect effects of the existence of executives who are publicly known as LGBT on the market value related to the adherence of investors themselves to the values that the ideas of fairness and equality represent or to the acknowledgement by investors of the positive effects directly or indirectly related to financial performance. Investors may acknowledge these benefits and act accordingly.

In line with the above, we present the following three hypotheses:

Hypothesis 1 (H1). The presence of successful LGBT executives has a direct effect on a firm's value.

Hypothesis 2 (H2). The presence of successful LGBT executives has a direct effect on a firm's financial performance.

Hypothesis 3 (H3). The presence of successful LGBT executives has an indirect effect on a firm's value, through a positive effect on the firm's financial performance.

\section{Research Design}

\subsection{Sample and Data}

The empirical study relies on the list of 100 leading LGBT executives published by OUTstading and The Financial Times (FT). These two organizations work together to publish the name of the 100 people who they think challenge the presumption that we cannot be openly LGBT and be successful in business. According to the methodology used by OUTstading and FT, everyone ranked in the list needed to be a success in their own right, influential within their sectors, and a role model who is lesbian, gay, bisexual, or transsexual (Sandhu 2015). The criteria include considerations of leadership, a look at where the individual sits within the organization, and how close they are to the group or chief executive (if not the chief executive itself), among others. Everyone also needs to be working in a business that operates as a for-profit organization. All the people included in the list are nominated by peers, and each person has given their permission to be included.

Based on the lists of 100 leading LGBT executives regarding the years 2013 to 2018, we hand-constructed a sample composed only of the publicly listed firms, excluding the non-listed firms, in which each of the LGBT executives are working (hereby identified as LGBT firms). Some of these firms have more than one executive in the aforementioned list, and not all of them appear in all the years, contributing to an unbalanced panel of LGBT firms. We then selected a matched sample of listed firms based on country and size (hereby identified as Non-LGBT firms). To do so, we collected information for all the listed Non-LGBT firms in the same country as each LGBT firm and selected the four observations for which the firm size based on total assets is nearest to the one of the LGBT firm. After eliminating extreme observations (when the distance from the mean was greater than three times the standard deviation), the final sample was composed of 972 firm-year observations.

Table 1 presents the sample distribution by country and by type of firm. LGBT firms contribute 187 firm-year observations during the sample period, representing $19 \%$ of the 
total sample. Firms from the United States and from the United Kingdom are the most representative, with around $44 \%$ and $34 \%$ of total observations, respectively.

Table 1. Sample distribution by country and by type of firm.

\begin{tabular}{cccc}
\hline Countries & $\begin{array}{c}\text { LGBT } \\
\text { Firms }\end{array}$ & $\begin{array}{c}\text { Non-LGBT } \\
\text { Firms }\end{array}$ & Total \\
\hline USA & 77 & 346 & 423 \\
\hline UK & 67 & 263 & 330 \\
\hline Germany & 8 & 32 & 40 \\
\hline Canada & 7 & 28 & 35 \\
\hline France & 7 & 28 & 35 \\
\hline Switzerland & 6 & 24 & 30 \\
\hline Australia & 5 & 24 & 29 \\
\hline Hong Kong & 4 & 16 & 20 \\
\hline Japan & 3 & 12 & 5 \\
\hline Finland & 1 & 4 & 5 \\
\hline The Netherlands & 1 & 4 & 5 \\
\hline South Korea & 1 & 4 & 972 \\
\hline All & 187 & 785 & \\
\hline
\end{tabular}

Table 2 displays the sample distribution by industry considering the Industry Classification Benchmark (ICB). The most representative industries are financial and consumer discretionary industries.

The firm data used to compute the variables included in the empirical study were collected from the Thomson Reuters Datastream. The country variables were collected from the World Bank and from the World Value Survey database.

\subsection{Simultaneous Estimation Model}

In order to investigate the effect of the existence of LBGT executives on firms' value, either directly or indirectly through its effect on a firm's financial performance, we estimate the following simultaneous equations model:

$$
\begin{gathered}
F_{-} \text {VALUE }_{i t}=\alpha_{0}+\alpha_{1} \text { LGBT }_{i t}+\alpha_{2} \text { ROA }_{i t}+\alpha_{3} \text { SIZE }_{i t}+\alpha_{4} L E V_{i t}+\alpha_{5} G R O W T H_{i t}+\alpha_{6} G D P_{i t}+\alpha_{7} H O M O_{i t}+\varepsilon \\
\text { ROA }_{i t}=\alpha_{0}+\alpha_{1} \text { LGBT }_{i t}+\alpha_{2} \text { SIZE }_{i t}+\alpha_{3} L E V_{i t}+\alpha_{4} \text { GROWTH }_{i t}+\alpha_{5} G D P_{i t}+\alpha_{6} \text { HOMO }_{i t}+\varepsilon
\end{gathered}
$$

where

Firm value is measured as Tobin's Q, defined as the sum of the market value of equity (share price multiplied by the number of ordinary shares in issue at fiscal year-end) and the book value of debt divided by the book value of total assets. Tobin's $Q$ has been extensively used in economics as a proxy for firm value (e.g., Demsetz and Villalonga 2001; Lang et al. 2003; Campbell and Mínguez-Vera 2008; Adams and Ferreira 2009; Carter et al. 2010; Greene and Jame 2013). 
Table 2. Sample distribution by industry.

\begin{tabular}{|c|c|c|c|c|c|c|c|c|c|c|c|c|}
\hline Country & $\begin{array}{c}\text { Basic } \\
\text { Materials }\end{array}$ & $\begin{array}{l}\text { Consumer } \\
\text { Staples }\end{array}$ & Financials & Health Care & Industrials & Technology & Telecomun. & Utilities & Real Estate & $\begin{array}{c}\text { Consumer } \\
\text { Discretionary }\end{array}$ & Energy & Total \\
\hline USA & 12 & 18 & 211 & 23 & 39 & 23 & 15 & 17 & 9 & 39 & 17 & 423 \\
\hline UK & 31 & 31 & 112 & 12 & 34 & 2 & 12 & 21 & 18 & 43 & 14 & 330 \\
\hline Germany & 0 & 0 & 22 & 1 & 0 & 2 & 0 & 4 & 2 & 9 & 0 & 40 \\
\hline Canada & 2 & 0 & 31 & 0 & 0 & 0 & 0 & 0 & 1 & 0 & 1 & 35 \\
\hline France & 0 & 0 & 20 & 0 & 2 & 3 & 0 & 0 & 1 & 6 & 3 & 35 \\
\hline Switzerland & 0 & 0 & 28 & 1 & 1 & 0 & 0 & 0 & 0 & 0 & 0 & 30 \\
\hline Australia & 4 & 1 & 12 & 0 & 2 & 0 & 1 & 0 & 7 & 2 & 0 & 29 \\
\hline Hong Kong & 1 & 0 & 1 & 0 & 1 & 2 & 0 & 0 & 10 & 5 & 0 & 20 \\
\hline Japan & 0 & 0 & 9 & 0 & 0 & 3 & 1 & 0 & 0 & 1 & 1 & 15 \\
\hline Finland & 2 & 0 & 1 & 0 & 0 & 0 & 1 & 1 & 0 & 0 & 0 & 5 \\
\hline The Netherlands & 0 & 0 & 3 & 0 & 1 & 0 & 0 & 0 & 0 & 0 & 1 & 5 \\
\hline South Korea & 0 & 0 & 4 & 0 & 0 & 1 & 0 & 0 & 0 & 0 & 0 & 5 \\
\hline India & 0 & 0 & 1 & 0 & 0 & 0 & 1 & 1 & 0 & 0 & 0 & 3 \\
\hline
\end{tabular}


LBGT is an indicator coded by 1 if the firm has an LGBT executive included in the list of 100 leading LGBT executives published by OUTstading and The Financial Times and 0 otherwise.

ROA is net income before extraordinary items divided by total assets.

SIZE is the natural logarithm of total assets.

LEV is the ratio of long-term debt to total assets.

GROWTH is the mean of sales growth in the last three years.

GDP is the natural logarithm of the GDP per capita as reported by the World Bank.

$\mathrm{HOMO}$ is a score that measures the extent to which people do not mind having homosexual people as neighbors, as reported by the World Values Survey.

The simultaneous estimation of those two structural equations has several advantages over the ordinary least squares (OLS) estimation of the single equations because it accounts for the interdependency between firm value and financial performance-the two dependent variables in each regression.

The problem of endogeneity and its underlying omitted variables usually affects researchers' results. The simultaneous estimation model has been used as a possible solution to mitigate that problem. We consider that a board's decision to appoint LGBT executives can be assumed to be an endogenous firm decision. We model our simultaneous estimation supported by this firm-decision condition.

The acceptability of the simultaneous estimation model is assessed by testing the null hypothesis of no systematic difference between the estimated coefficients of the simultaneous model and those of the OLS model (Hausman test), and the null is rejected at the $1 \%$ level. The use of a simultaneous estimation model permits the treatment of the correlation between the error terms of the equations in the system (not considered in OLS estimation) as well as the handling of the endogeneity problem. The models are estimated with industry-fixed effects.

Our argument is that firms with LGBT executives included in the 100 leading LGBT executives published by OUTstading and The Financial Times are more likely to signal a more progressive environment in terms of LGBT rights, which investors will reward positively. These firms are also expected to enjoy the benefits mentioned above, both those related to human capital and reputational benefits, which will lead to enhanced financial performance, which, in turn, will have a positive effect on firm value.

\section{Research Findings}

\subsection{Descriptive Analysis}

Table 3 reports the descriptive statistics of the variables used in the simultaneous estimation model. On average, Tobin's Q is 0.8142, and it ranges from 0.0191 to 3.8323. The mean value of the variable ROA is 0.0313 , and it ranges from -0.1481 and 0.2219 . On average, LEV and GROWTH are 0.1661 and 0.0390, respectively. Regarding the country variables, the mean value of GDP is 10.8211, ranging from 10.3533 (South Korea) to 11.3691 (Switzerland). The mean value of $\mathrm{HOMO}$ is 0.7745 , ranging from 0.17 (South Korea) to 0.86 (Switzerland).

Table 4 presents the correlations between variables. Consistent with previous literature, there is a high positive correlation between the financial performance variable (ROA) and Tobin's Q (F_Value). It is also worth noting that our variable of interest, the existence of LGBT executives, is significantly and positively correlated with ROA and F_Value. This initial finding corroborates the hypotheses proposed in this research. 
Table 3. Descriptive statistics of variables.

\begin{tabular}{cccccc}
\hline Variable & Obs. & Mean & Std. Dev. & Min & Max \\
\hline F_VALUE & 972 & 0.8142 & 0.7358 & 0.0191 & 3.8323 \\
ROA & 972 & 0.0313 & 0.0460 & -0.1481 & 0.2219 \\
LGBT & 972 & 0.1924 & 0.3944 & 0 & 1 \\
SIZE & 972 & 17.8679 & 2.1293 & 10.8611 & 21.6650 \\
LEV & 972 & 0.1661 & 0.1409 & 0 & 0.6381 \\
GROWTH & 972 & 0.0390 & 0.1198 & -0.4230 & 0.5451 \\
GDP & 972 & 10.8211 & 0.2523 & 7.6059 & 11.3691 \\
HOMO & 972 & 0.7745 & 0.0930 & 0.1700 & 0.8600 \\
\hline
\end{tabular}

F_VALUE is measured as Tobin's Q, defined as of the sum of the market value of equity (share price multiplied by the number of ordinary shares in issue at fiscal year-end) and the book value of debt divided by the book value of total assets. ROA is net income before extraordinary items divided by total assets. LBGT is an indicator coded by 1 if the firm has an LGBT executive included in the list of 100 leading LGBT Executives published by OUTstading and The Financial Times and 0 otherwise. SIZE is the natural logarithm of total assets. LEV is the ratio of long-term debt to total assets. GROWTH is the mean of sales growth in the last three years. GDP is the natural logarithm of the GDP per capita as reported by the World Bank. HOMO is a score that measure the extent to which people do not mind having homosexual people as neighbors, as reported by the World Values Survey.

Table 4. Correlation table.

\begin{tabular}{|c|c|c|c|c|c|c|c|}
\hline & F_VALUE & ROA & LGBT & SIZE & LEV & GROWTH & GDP \\
\hline F_VALUE & 1 & - & - & - & - & - & - \\
\hline ROA & $0.683^{* * *}$ & 1 & - & - & - & - & - \\
\hline LGBT & $0.179 * * *$ & $0.164^{* * *}$ & 1 & - & - & - & - \\
\hline SIZE & $-0.461^{* * *}$ & $-0.375^{* * *}$ & $0.075^{* *}$ & 1 & - & - & - \\
\hline LEV & $0.442^{* * *}$ & $0.169^{* * *}$ & -0.018 & $-0.283^{* * *}$ & 1 & - & - \\
\hline GROWTH & $0.095^{* * *}$ & $0.127^{* * *}$ & -0.041 & $-0.240^{* * *}$ & 0.014 & 1 & - \\
\hline GDP & 0.007 & -0.012 & 0.005 & $0.151^{* * *}$ & -0.003 & -0.045 & 1 \\
\hline HOMO & $0.059 *$ & 0.038 & 0.009 & 0.041 & 0.036 & -0.003 & $0.167^{* * *}$ \\
\hline
\end{tabular}

F_VALUE is measured as Tobin's Q, defined as of the sum of the market value of equity (share price multiplied by the number of ordinary shares in issue at fiscal year-end) and the book value of debt divided by the book value of total assets. ROA is net income before extraordinary items divided by total assets. LBGT is an indicator coded by 1 if the firm has an LGBT executive included in the list of 100 leading LGBT executives published by OUTstading and The Financial Times and 0 otherwise. SIZE is the natural logarithm of total assets. LEV is the ratio of long-term debt to total assets. GROWTH is the mean of sales growth in the last three years. GDP is the natural logarithm of the GDP per capita as reported by the World Bank. HOMO is a score that measure the extent to which people do not mind having homosexual people as neighbors, as reported by the World Values Survey. ***,**** indicate statistical significance at 1, 5, and $10 \%$ levels of statistical significance for two-tailed tests.

Regarding the control variables, GDP is the only variable that is not statistically correlated with F_Value. LEV and GROWTH are positively correlated with F_Value, while the SIZE variable is negatively correlated.

\subsection{Simultaneous Estimation Results}

Table 5 presents the results for the simultaneous estimation regression model. The first part of Table 5 shows the results for the first equation in the model (Equation (1)), which aims to capture the direct and the indirect effects of the independent variables in the firm value (F_VALUE) through their effects on the financial performance indicator (ROA). The second part of Table 5 presents the estimation results for the second equation in the model (Equation (2)), which aims to capture the direct effect of the independent variables on the ROA. 
Table 5. Results of the simultaneous estimation.

\begin{tabular}{ccccc}
\hline & Estimate & Std. Error & t Value & $p$-Value \\
\hline F_VALUE (Equation (1)) & & & & \\
LGBT & 0.161 & 0.034 & 4.781 & 0.000 \\
ROA & 7.158 & 0.334 & 21.416 & 0.000 \\
SIZE & -0.039 & 0.008 & -4.938 & 0.000 \\
LEV & 0.914 & 0.112 & 8.138 & 0.000 \\
GROWTH & -0.004 & 0.111 & -0.035 & 0.972 \\
GDP & 0.113 & 0.052 & 2.173 & 0.030 \\
HOMO & 0.270 & 0.140 & 1.922 & 0.055 \\
cons & -0.568 & 0.558 & -1.017 & 0.309 \\
ROA (Equation (2)) & & & & \\
LGBT & 0.013 & 0.003 & 3.930 & 0.000 \\
SIZE & -0.004 & 0.001 & -4.866 & 0.000 \\
LEV & -0.025 & 0.011 & -2.350 & 0.019 \\
GROWTH & 0.010 & 0.011 & 0.913 & 0.361 \\
GDP & 0.006 & 0.005 & 1.288 & 0.198 \\
HOMO & 0.030 & 0.014 & 2.221 & 0.027 \\
_cons & -0.014 & 0.054 & -0.262 & 0.793 \\
\hline Industry dummies & YES & & & \\
No observations & 972 & & & \\
R2 (Equation (1)) & 0.719 & & & \\
R2 (Equation (2)) & 0.326 & & &
\end{tabular}

$\overline{\text { F_VALUE is measured as Tobin's Q, defined as of the sum of the market value of equity (share price multiplied }}$ by the number of ordinary shares in issue at fiscal year-end) and the book value of debt divided by the book value of total assets. ROA is net income before extraordinary items divided by total assets. LBGT is an indicator coded by 1 if the firm has an LGBT executive included in the list of 100 leading LGBT executives published by OUTstading and The Financial Times and 0 otherwise. SIZE is the natural logarithm of total assets. LEV is the ratio of long-term debt to total assets. GROWTH is the mean of sales growth in the last three years. GDP is the natural logarithm of the GDP per capita as reported by the World Bank. HOMO is a score that measure the extent to which people do not mind having homosexual people as neighbors, as reported by the World Values Survey. INDUSTRY effects included.

The results of the first equation, in the first part of Table 5 , indicate that the coefficient of the LGBT variable is positive and statistically significant (coefficient: $0.161 ; p$-value: 0.000 ), which means the existence of LGBT executives has a direct effect on a firm's value. This finding is consistent with hypothesis 1 . Having LGBT executives seems to be valued by investors for its own sake, not only due to its impact on financial performance. We view this finding as consistent with the results of studies that find a positive impact of diversity awards on share prices (Cook and Glass 2014) or of changes in corporate equality index scores on stock prices (Wang and Schwarz 2010).

The results of the second equation, in the second part of Table 5, indicate that the coefficient of the LGBT variable is positive and statistically significant (coefficient: 0.013; $p$-value: 0.000), which means that the existence of LGBT executives also has a direct effect of the ROA. This is consistent with hypothesis 2 . It is also consistent with existing literature that finds that LGBT-friendly firms are likely to present higher levels of ROA (Fatmy et al. 2021) and income per employee (Shan et al. 2017).

Additionally, the coefficient of the variable ROA in Equation (1) is positive and statistically significant (coefficient: 7.158; $p$-value: 0.000 ), meaning that the ROA has a direct effect on the firms' value. Therefore, we may conclude that there is an indirect relationship between the presence of LGBT executives and firm value, which is captured by the financial performance indicator ROA. This finding is consistent with hypothesis 3 . Although existing studies have not made an analysis similar to that which we present in this study, we view this finding as consistent with existing literature that presents evidence of a positive association between LGBT policies and firm value (Shan et al. 2017; Pichler et al. 2018; Fatmy et al. 2021). What is lacking in these studies is the examination of whether such association is driven by the impact of LGBT policies on financial performance. 
Regarding the control variables, the results of the first equation show the coefficients of the variables LEV, GDP, and HOMO are positive and statistically significant, meaning that more leveraged firms and firms from countries with a higher GDP per capita and/or a higher level of tolerance of LGBT people are associated with a higher firm value. By contrast, the coefficient of the SIZE variable is negative and statistically significant. Regarding the second equation, we find that the coefficients of the variables SIZE and LEV are negative and statistically significant, meaning that larger and more leveraged firms are less profitable. By contrast, firms from countries with a higher level of tolerance of LGBT are positively associated with higher financial performance.

\subsection{Additional Analysis}

In order to increase the robustness of the results, we also estimate the simultaneous equations model, adding an interaction term of the variables LGBT and Non_HOMO, which measure the extent to which the firms with LGBT executives are based in a country in which people do not like having homosexual people as neighbors. The results, presented in Table 6, show that the effect of LBGT executives on a firm's value, either directly or indirectly through their effect on the firm financial performance, is significantly lower in the countries where people do not like having a homosexual person as a neighbor. This finding is consistent with Fatmy et al. (2021), who, using a US sample, found the positive effect of LGBT policies on firm value and financial performance to be more pronounced for firms located in more liberal states when compared to those located in more conservative states.

Table 6. Results of the simultaneous estimation (additional analysis).

\begin{tabular}{|c|c|c|c|c|}
\hline & Estimate & Std. Error & t Value & $p$-Value \\
\hline \multicolumn{5}{|l|}{ F_VALUE (Equation (1)) } \\
\hline LGBT & 0.442 & 0.079 & 5.623 & 0.000 \\
\hline $\mathrm{ROA}$ & 7.113 & 0.332 & 21.412 & 0.000 \\
\hline SIZE & -0.039 & 0.008 & -4.942 & 0.000 \\
\hline LEV & 0.893 & 0.112 & 7.984 & 0.000 \\
\hline GROWTH & -0.009 & 0.110 & -0.086 & 0.932 \\
\hline GDP & 0.125 & 0.051 & 2.454 & 0.014 \\
\hline LGBTxNon_HOMO & -1.267 & 0.323 & -3.929 & 0.000 \\
\hline _cons & -0.496 & 0.555 & -0.893 & 0.372 \\
\hline \multicolumn{5}{|l|}{ ROA (Equation (2)) } \\
\hline LGBT & 0.028 & 0.008 & 3.669 & 0.000 \\
\hline SIZE & -0.004 & 0.001 & -4.812 & 0.000 \\
\hline LEV & -0.026 & 0.011 & -2.424 & 0.016 \\
\hline GROWTH & 0.010 & 0.011 & 0.918 & 0.359 \\
\hline GDP & 0.008 & 0.005 & 1.632 & 0.103 \\
\hline LGBTxNon_HOMO & -0.068 & 0.031 & -2.173 & 0.030 \\
\hline _cons & -0.009 & 0.054 & -0.172 & 0.864 \\
\hline Industry dummies & YES & & & \\
\hline No observations & 972 & & & \\
\hline R2 (Equation (1)) & 0.723 & & & \\
\hline R2 (Equation (2)) & 0.326 & & & \\
\hline \multicolumn{5}{|c|}{$\begin{array}{l}\text { F_VALUE is measured as Tobin's Q, defined as of the sum of the market value of equity (share price multiplied } \\
\text { by the number of ordinary shares in issue at fiscal year-end) and the book value of debt divided by the book } \\
\text { value of total assets. ROA is net income before extraordinary items divided by total assets. LBGT is an indicator } \\
\text { coded by } 1 \text { if the firm has an LGBT executive included in the list of } 100 \text { leading LGBT executives published by } \\
\text { OUTstading and The Financial Times and } 0 \text { otherwise. SIZE is the natural logarithm of total assets. LEV is the } \\
\text { ratio of long-term debt to total assets. GROWTH is the mean of sales growth in the last three years. GDP is the } \\
\text { natural logarithm of the GDP per capita as reported by the World Bank. HOMO is a score that measure the extent } \\
\text { to which people do not mind having homosexual people as neighbors, as reported by the World Values Survey. } \\
\text { INDUSTRY effects included. }\end{array}$} \\
\hline
\end{tabular}




\section{Discussion}

As predicted, our findings suggest that firms with known LGBT executives outperform their counterparts. By using a simultaneous equations model, based on the results of the two equations considered taken together, we detected that the presence of LGBT executives directly affects a firm's value, and it also has a positive impact on financial performance, which in turn positively impacts the firm's value. This result is consistent with the idea that firms with known LGBT executives are able to attract and retain wellqualified employees, generate organizational commitment on their part, and obtain publicly favorable reputations that allow them to outperform their counterparts in terms of financial performance. As mentioned above, this financial performance is dependent both on human capital aspects (quality and commitment of the workforce) and on reputational aspects (the capacity of attracting customers). We interpret this as evidence of what Johnston and Malina (2008, p. 620) call "employee and customer goodwill" towards sexual orientation and corporate practices and policies encouraging diversity. This finding is consistent with the findings of the few studies that have analyzed the economic benefits of LGBT-friendly policies and practices (Johnston and Malina 2008; Wang and Schwarz 2010; Sears and Mallory 2014; Shan et al. 2017; Pichler et al. 2018).

We also found a significant direct relationship between the presence of LGBT executives and firm value. This finding is consistent with Wang and Schwarz (2010), whose findings suggest that firms with more progressive LGBT-friendly policies in place subsequently enjoy a higher annual share price growth than their counterparts. However, although not contrary to the results of Johnston and Malina (2008), our findings are not entirely consistent with them. Johnston and Malina (2008) examined the impact of the inaugural corporate equality index on firms' stock market value and found that shareholders do not penalize firms for allocating resources to progressive sexual orientation workplace policies. Whereas Johnston and Malina (2008) examined the short-term financial impact of LGBT-friendly policies, Wang and Schwarz (2010) investigated the long-term impact of such policies. However, Wang and Schwarz (2010) have not examined the effect of profitability on market value as we have done. We add to their analysis by considering this mediation. It is possible that the findings of Wang and Schwarz (2010) were driven by profitability, instead of LGBT-friendly policies having a direct impact on firm value.

Our results are also consistent with those of Shan et al. (2017), who found that companies with higher degrees of corporate sexual equality enjoy higher stock returns and market valuation. These researchers have also identified one channel through which companies benefit from higher degrees of corporate sexual equality—higher employee productivity. They suggested that the relationship between corporate sexual equality and firm value would be partially mediated by the relationship between employee productivity and firm performance. However, they have not examined the effects of this higher employee productivity on companies' financial performance. They acknowledged other plausible channels, such as the case of the possible effect of LGBT-friendly policies and practices on consumers. They left this issue for future research.

Our approach was different. In this study, we examined the direct effect of a firm's LGBT-friendliness reputation on their market value, as well as the indirect effect via the effect on financial performance, presumably driven by the effects of a company's reputation of being progressive in terms of how LGBT workers are treated on the quality and commitment of the workforce and its attractiveness to well-qualified employees and customers. We leave the examination of the functioning of these two different channels to future research.

We interpret our results as meaning that the reputational signal for investors of established progressive LGBT-friendly policies, which is consistent with the overall findings in the existing literature, is currently of a similar (or almost similar) magnitude to that of the presence of known LGBT executives in a firm's leadership. The findings of Johnston and Malina (2008) mentioned above may be related to a certain lack of attention to LGBT issues on the part of investors, which, meanwhile, has given way to some attentiveness to such 
issues in the past few years. Cook and Glass (2014) found a significant increase in the share price of firms that received certain diversity awards following their announcement, which was interpreted by these authors as meaning that investors view diversity reputation signals as indicating good health for firms. However, they also found that signals associated with the advancement of women are much more likely to be rewarded by investors than those associated with the advancement of racial/ethnic minorities. Given that, among the various elements of diversity, the issue of sexual orientation and identity is the last acceptable prejudice or bias (Day and Greene 2008; Ozeren 2014), it is not all that unexpected that investors were not particularly sensitive to it. This is likely to have changed, however slightly, in the past few years.

It seems as though the rising awareness of sexual orientation and identity issues among policymakers and firms' stakeholders, in general, has made investors more attentive to LGBT issues and/or to the employee and customer goodwill-related benefits firms enjoy by being and/or being perceived as being preoccupied with LGBT rights.

\section{Conclusions}

Our study contributes to the scant literature on LGBT-friendly firms and the relationship of such friendliness with market value by exploring a hitherto unexplored aspect: that of the presence of LGBT executives in firms' leadership teams. Our findings suggest that having visible LGBT people at the upper echelons is likely to contribute positively to a firm's performance. We suggest that two different channels may be at work: a direct effect of an LGBT-friendliness reputation on market value, and an indirect effect related to the effects of this reputation on financial performance, presumably associated with the impacts of such a reputation on the quality and commitment of the workforce and on the attractiveness to employees and customers. The findings are consistent with the lens of analysis proposed. It seems that the presence of LGBT people in the upper echelons offers a signal to a firm's stakeholders that has effects regarding how they engage with the firm, whether this concerns investors, employees, or consumers.

This study has some practical managerial implications. It can help managers and organizations to become aware of the positive influence of the presence of LGBT people in the upper echelons on a firm's reputation, financial performance, and market value. Firms would well advised to welcome and promote the presence of LGBT people in leadership teams.

However, this study also has limitations, among which are those pertaining to the dependent variable retained, the presence of known LGBT executives on the leadership team of a firm, which we equate with having progressive LGBT-friendly policies and practices in place. Another limitation is that our sample included firms exclusively from developed countries, supposedly with a high recognition of LGBT rights.

Future research should try to distinguish the reputational effects of having such policies in place from the reputational impacts of the presence of LGBT executives. Further research should also extend the analysis conducted in this study to the cases of countries without such recognition and, more generally, with very different socio-cultural contexts.

Author Contributions: Conceptualization, I.C.L. and A.I.L.; methodology, I.C.L., A.I.L. and R.W.S.; formal analysis, R.W.S.; investigation, I.C.L., A.I.L. and R.W.S.; writing-original draft preparation, I.C.L., A.I.L., D.D.M. and M.C.B.; writing-review and editing, I.C.L., A.I.L., D.D.M., M.T.S. and M.C.B. All authors have read and agreed to the published version of the manuscript.

Funding: This research received no external funding.

Institutional Review Board Statement: Not applicable.

Informed Consent Statement: Not applicable.

Data Availability Statement: Not applicable.

Conflicts of Interest: The authors declare no conflict of interest. 


\section{References}

Adams, Renée, and Daniel Ferreira. 2009. Women in the boardroom and their impact on governance and performance. Journal of Financial Economics 94: 291-309. [CrossRef]

Al-Shaer, Habiba, and Mahbub Zaman. 2016. Board gender diversity and sustainability reporting quality. Journal of Contemporary Accounting \& Economics 12: 210-22.

Arayssi, Mahmoud, Mustafa Dah, and Mohammad Jizi. 2016. Women on boards, sustainability reporting and firm performance. Sustainability Accounting, Management and Policy Journal 7: 376-401. [CrossRef]

Arenas, Alicia, Donatela Di Marco, Lourdes Munduate, and Martin C. Euwema. 2017. Shaping Inclusive Organizations through Social Dialogue. Cham: Springer International.

Badgett, M. V. Lee, Laura E. Durso, Angeliki Kastanis, and Christy Mallory. 2013. The Business Impact of LGBT-Supportive Workplace Policies. The Williams Institute, UCLA. Available online: https:/ / williamsinstitute.law.ucla.edu/wp-content/uploads/BusinessImpact-of-LGBT-Policies-May-2013.pdf (accessed on 1 November 2020).

Barney, Jay. 1991. Firm resources and sustained competitive advantage. Journal of Management 17: 99-120. [CrossRef]

Barney, Jay B., David J. Ketchen, and Mike Wright. 2021. Resource-Based Theory and the Value Creation Framework. Journal of Management 47: 1936-55. [CrossRef]

Barney, Jay B., David J. Ketchen, and Mike Wright. 2011. The Future of Resource-Based Theory: Revitalization or Decline? Journal of Management 37: 1299-316. [CrossRef]

Bowen, Howard R. 1953. Social Responsibility of the Business Man. New York: Harper \& Row.

Branco, Manuel Castelo, and Lúcia Lima Rodrigues. 2006. Corporate social responsibility and resource based perspectives. Journal of Business Ethics 69: 111-32. [CrossRef]

Burdenson, J. Stuart, and Gerben S. Van der Vegt. 2018. Diversity and Inequality in Management Teams: A Review and Integration of Research on Vertical and Horizontal Member Differences. Annual Review of Organizational Psychology and Organizational Behavior 5: 47-73.

Cabrera-Fernández, Ana Isabel, Rocío Martínez-Jiménez, and María Jesús Hernández-Ortiz. 2016. Women's participation on boards of directors: A review of the literature. International Journal of Gender and Entrepreneurship 8: 69-89. [CrossRef]

Campbell, Kevin, and Antonio Mínguez-Vera. 2008. Gender Diversity in the Boardroom and Firm Financial Performance. Journal of Business Ethics 83: 435-51. [CrossRef]

Carter, David A., Frank D'Souza, Betty J. Simkins, and W. Gary Simpson. 2010. The gender and ethnic diversity of US boards and board committees and firm financial performance. Corporate Governance 18: 396-414. [CrossRef]

Chintrakarn, Pandej, Sirimon Treepongkaruna, Pornsit Jiraporn, and Sang Mook Lee. 2020. Do LGBT-supportive corporate policies improve credit ratings? An instrumental-variable analysis. Journal of Business Ethics 162: 31-45. [CrossRef]

Clair, Judith A., Joy E. Beatty, and Tammy L. MacLean. 2005. Out of sight but not out of mind: Managing invisible social identities in the workplace. Academy of Management Review 30: 78-95. [CrossRef]

Colgan, Fiona. 2011. Equality, diversity and corporate responsibility: Sexual orientation and diversity management in the UK private sector. Equality, Diversity and Inclusion: An International Journal 30: 719-34. [CrossRef]

Cook, Alison, and Christy Glass. 2014. Do Diversity Reputation Signals Increase Share Value? Human Resource Development Quarterly 25: 471-91. [CrossRef]

Cook, Alison, and Christy Glass. 2016. Do women advance equity? The effect of gender leadership composition on LGBT-friendly policies in American firms. Human Relations 69: 1431-56. [CrossRef]

Cronin, Mhatthew A., and Laurie R. Weingart. 2007. Representational gaps, information processing, and conflict in functionally diverse teams. Academy of Management Review 32: 761-73. [CrossRef]

Day, Nancy E., and Patricia G. Greene. 2008. A case for sexual orientation diversity management in small and large organizations. Human Resource Management 47: 637-54. [CrossRef]

Demsetz, Harold, and Belén Villalonga. 2001. Ownership structure and corporate performance. Journal of Corporate Finance 7: 209-33. [CrossRef]

Di Marco, Donatella. 2017. Unlocking Closets at Organizations. In Shaping Inclusive Workplaces Through Social Dialogue. Edited by Alicia Arenas, Donatella Di Marco, Lourdes Munduate and Martin Euwema. Cham: Springer International, pp. 187-200.

Di Marco, Donatella, Helge Hoel, Alicia Arenas, and Lourdes Munduate. 2018. Workplace incivility as modern sexual prejudice. Journal of Interpersonal Violence 33: 1978-2004. [CrossRef]

Einarsdóttir, Anna, Helge Hoel, and Duncan Lewis. 2015. 'It's nothing personal': Anti-homosexuality in the British workplace. Sociology 49: 1183-99. [CrossRef]

European Commission (EC). 2011. Communication from the Commission to the European Parliament, the Council, the European Economic and Social Committee and the Committee of the Regions. A renewed EU strategy 2011-14 for Corporate Social Responsibility. COM 2011(681) Final. Brussels: European Commission.

Everly, Benjamin A., and Joshua L. Schwarz. 2015. Predictors of the adoption of LGBT-friendly HR policies. Human Resource Management 54: 367-84. [CrossRef]

Farndale, Elaine, Michal Biron, Dennis R. Briscoe, and Sumita Raghuram. 2015. A global perspective on diversity and inclusion in work organisations. The International Journal of Human Resource Management 26: 677-87. [CrossRef] 
Fatmy, Veda, John Kihn, Jukka Sihvonen, and SamiVähämaa. 2021. Does Lesbian and Gay Friendliness Pay Off? A New Look at LGBT Policies and Firm Performance. Accounting \& Finance. [CrossRef]

Fitzsimmons, Terrance W., and Victor J. Callan. 2020. The diversity gap in leadership: What are we missing in current theorizing? The Leadership Quarterly 31: 101347. [CrossRef]

Gonzalez, Jorge A., and Angelo S. DeNisi. 2009. Cross-level effects of demography and diversity climate on organizational attachment and firm effectiveness. Journal of Organizational Behavior 30: 21-40. [CrossRef]

Greene, T. Clifton, and Russell Jame. 2013. Company name fluency, investor recognition, and firm value. Journal of Financial Economics 109: 813-834. [CrossRef]

Halliday, Cynthia Saldanha, Samantha C. Paustian-Underdahl, and Stav Fainshmidt. 2021. Women on Boards of Directors: A Meta-Analytic Examination of the Roles of Organizational Leadership and National Context for Gender Equality. Journal of Business and Psychology 36: 173-91. [CrossRef]

Hayworth, Gene H. 2008. Gay rights. In Encyclopedia of Business Ethics and Society. Edited by Robert W. Kolb. Thousand Oaks: SAGE Publications, pp. 972-77.

Hossain, Mohammed, Muhammad Atif, Ammad Ahmed, and Lokman Mia. 2020. Do LGBT workplace diversity policies create value for firms? Journal of Business Ethics 167: 775-91. [CrossRef]

Huffman, Ann H., Kristen M. Watrous-Rodriguez, and Eden B. King. 2008. Supporting a diverse workforce: What type of support is most meaningful for lesbian and gay employees? Human Resource Management 47: 237-53. [CrossRef]

Human Rights Campaign Foundation HRCF. 2015. Corporate Equality Index 2016. Retrieved 30 November 2016. Available online: hrc-assets.s3-website-us-east-1.amazonaws.com/ / files/assets/respurces /CEI-2016-FullReport.pdf (accessed on 1 November 2020).

Hur, Hyunkang. 2020. The role of inclusive work environment practices in promoting LGBT employee job satisfaction and commitment. Public Money \& Management 40: 426-36.

Ionescu, Luminita. 2020. The economics of the carbon tax: Environmental performance, sustainable energy, and green financial behavior. Geopolitics, History, and International Relations 12: 101-7.

Ionescu, Luminita. 2021. Transitioning to a low-carbon economy: Green financial behavior, climate change mitigation, and environmental energy sustainability. Geopolitics, History, and International Relations 13: 86-96.

Jiraporn, Pornsit, Denise Potosky, and Sang Mook Lee. 2019. Corporate governance and lesbian, gay, bisexual, and transgendersupportive human resource policies from corporate social responsibility, resource-based, and agency perspectives. Human Resource Management 58: 317-36. [CrossRef]

Johnston, Derek, and Mary A. Malina. 2008. Managing sexual orientation diversity: The impact on firm value. Group and Organization Management 33: 602-25. [CrossRef]

Kossek, Ellen Erns, and Shaun Pichler. 2007. EEO and the management of diversity. In Oxford Handbook of Human Resource Management. Edited by Peter Boxall, John Purcell and Patrick M. Wright. Oxford: Oxford University Press, pp. 251-72.

Kyaw, Khine, Sirirmon Treepongkaruna, and Pornsit Jiraporn. 2021a. Stakeholder engagement and firms' innovation: Evidence from LGBT-supportive policies. Corporate Social Responsibility and Environmental Management 28: 1285-98. [CrossRef]

Kyaw, Khine, Sirimon Treepongkaruna, Pornsit Jiraporn, and Chaiyuth Padungsaksawasdi. 2021b. Does board gender diversity improve the welfare of lesbian, gay, bisexual, and transgender employees? Corporate Social Responsibility and Environmental Management. [CrossRef]

Lang, Mark. H., Karl V. Lins, and Darius P. Miller. 2003. ADRs, analysts, and accuracy: Does cross-listing in the U.S. improve a firm's information environment and increase market value? Journal of Accounting Research 41: 317-345. [CrossRef]

Li, Feng, and Venky Nagar. 2013. Diversity and performance. Management Science 593: 529-44. [CrossRef]

Lourenço, Isabel Costa, Jeffrey Callen, Manuel Castelo Branco, and João Dias Curto. 2014. The value relevance of reputation for sustainability leadership. Journal of Business Ethics 119: 17-28. [CrossRef]

Lozano, Rodrigo, Angela Carpenter, and Donald Huisingh. 2015. A review of 'theories of the firm' and their contributions to Corporate Sustainability. Journal of Cleaner Production 106: 430-42. [CrossRef]

Malik, Mahfuja. 2015. Value-Enhancing Capabilities of CSR: A Brief Review of Contemporary Literature. Journal of Business Ethics 127: 419-38. [CrossRef]

Mallory, Christy, Brad Sears, Eric R. Wright, and Kerith J. Conron. 2017. The Economic Impact of Stigma and Discrimination against LGBT People in Georgia. UCLA: The Williams Institute. Available online: https://williamsinstitute.law.ucla.edu/wp-content/ uploads/Impact-LGBT-Discrimination-GA-Jan-2017.pdf (accessed on 1 February 2021).

McFadden, Ciarán. 2015. Lesbian, Gay, Bisexual, and Transgender careers and human resource development: A systematic literature review. Human Resource Development Review 14: 125-62. [CrossRef]

McKinsey and Company. 2018. Delivery through Diversity. McKinsey and Company. Available online: https://www.mckinsey. $\mathrm{com} / \sim\{\} /$ media/McKinsey/Business\%20Functions/Organization/Our\%20Insights/Delivering\%20through\%20diversity / Delivering-through-diversity_full-report.ashx (accessed on 1 January 2021).

McWilliams, Abagail, and Donald S. Siegel. 2011. Creating and capturing value: Strategic corporate social responsibility, resource-based theory and sustainable competitive advantage. Journal of Management 37: 1480-95. [CrossRef]

Nielsen, Sabina, and Morten Huse. 2010. The Contribution of Women on Boards of Directors: Going beyond the Surface. Corporate Governance: An International Review 18: 136-48. [CrossRef] 
Opall, Brent S. 2021. Motives in creating an LGBTQ inclusive work environment: A case study. Qualitative Research in Organizations and Management: An International Journal 16: 237-60. [CrossRef]

Özbilgin, Mustafa, Ahu Tatli, Gulce Ipek, and Mohammad Sameer. 2016. Four approaches to accounting for diversity in global organisations. Critical Perspectives on Accounting 35: 88-99. [CrossRef]

Ozeren, Emir. 2014. Sexual Orientation Discrimination in the Workplace: A Systematic Review of Literature. Procedia-Social and Behavioral Sciences 109: 1203-15. [CrossRef]

Patel, Pankaj C., and Cong Feng. 2021. LGBT Workplace Equality Policy and Customer Satisfaction: The Roles of Marketing Capability and Demand Instability. Journal of Public Policy E Marketing 40: 7-26.

Pichler, Shaun, Janell L. Blazovich, Kirsten A. Cook, Janet M. Huston, and William R. Strawser. 2018. Do LGBT-supportive corporate policies enhance firm performance? Human Resource Management 57: 263-78. [CrossRef]

Post, Corinne, and Kris Byron. 2015. Women on Boards and Firm Financial Performance: A Meta-Analysis. Academy of Management Journal 58: 1546-71. [CrossRef]

Ragins, Belle Rose. 2004. Sexual orientation in the workplace: The unique work and career experiences of gay, lesbian and bisexual workers. Research in Personnel and Human Resources Management 23: 35-129.

Ragins, Belle Rose. 2008. Disclosure disconnects: Antecedents and consequences of disclosing invisible stigmas across life domains. Academy of Management Review 33: 194-215. [CrossRef]

Randel, Amy E., and Kimberly S. Jaussi. 2003. Functional background identity, diversity, and individual performance in cross-functional teams. Academy of Management Journal 46: 763-74.

Roberson, Quinetta M., and Hyeon Jeong Park. 2007. Examining the Link Between Diversity and Firm Performance. The Effects of Diversity Reputation and Leader Racial Diversity. Group E Organization Management 32: 548-68.

Roumpi, Dorothea, Panagiotis Giannakis, and John E. Delery. 2020. Adoption of LGBT-friendly practices: The effect of institutional pressure and strategic choice. Human Resource Management Journal 30: 604-623. [CrossRef]

Sandhu, Suki. 2015. Methodology of the 2015 OUTstanding/FT LGBT Rankings. Published online in Financial Times. 20 October 2016. Available online: https: / / www.ft.com/ content/9d537bfe-70dd-11e5-9b9e-690fdae72044 (accessed on 1 January 2021).

Sears, Brad, and Christy Mallory. 2014. How LGBT-Related Workplace Policies Can Have a Positive Impact on the Corporate Bottom Line. In Gender Identity and Sexual Orientation Discrimination in the Workplace: A Practical Guide. Edited by Christine Michelle Duffy. Arlington: Bloomberg NBA.

Shan, Liwei, Shihe Fu, and Lu Zheng. 2017. Corporate sexual equality and firm performance. Strategic Management Journal 38: 1812-26. [CrossRef]

Shaukat, Amama, Yan Qiu, and Grzegorz Trojanowski. 2016. Board Attributes, Corporate Social Responsibility Strategy, and Corporate Environmental and Social Performance. Journal of Business Ethics 135: 569. [CrossRef]

Stavrou, Eleni, and Christiana Ierodiakonou. 2018. Expanding the work-life balance discourse to LGBT employees: Proposed research framework and organizational responses. Human Resource Management 57: 1355-70. [CrossRef]

Surroca, Jordi, Josep A. Tribó, and Sandra Waddock. 2010. Corporate Responsibility and Financial Performance: The Role of Intangible Resources. Strategic Management Journal 31: 463-90. [CrossRef]

Tejeda, Manuel J. 2006. Nondiscrimination Policies and Sexual Identity Disclosure: Do They Make a Difference in Employee Outcomes? Employee Responsibilities and Rights Journal 18: 45-59. [CrossRef]

Tetrault Sirsly, Carol-Ann, and Elena Lvina. 2019. From doing good to looking even better: The dynamics of CSR and reputation. Business E Society 58: 1234-66.

van Knippenberg, Daan, and Julija N. Mell. 2016. Past, present, and potential future of team diversity research: From compositional diversity to emergent diversity. Organizational Behavior and Human Decision Processes 136: 135-45. [CrossRef]

Wang, Peng, and Joshua L. Schwarz. 2010. Stock price reactions to GLBT non-discrimination policies. Human Resource Management 49: 195-216. [CrossRef] 